УДК 340.12

DOI https://doi.org/10.32838/TNU-2707-0581/2021.1/02

\title{
Мозолюк-Боднар Л.М.
}

Хмельницький інститут соціальних технологій

Відкритого міжнародного університету розвитку людини «Україна»

\section{ВПЛИВ ЮРИДИЧНОЇ ТЕХНІКИ НА ЗМІЦНЕННЯ ДЕРЖАВНОЇ ДИСЦИПЛІНИ: ТЕОРЕТИЧНИЙ АСПЕКТ ДОСЛІДЖЕННЯ}

У статті проаналізовано вплив юридичної техніки на зміџнення держсвної дисципліни. Визначено, щзо основним призначенням юридичної техніки є точний, повний, чіткий, правильний виклад акта-волевиявлення в акті-документі, відображення в тексті документа справжньої волі правотвория. Зазначено, що якість юридичної техніки впливає на реалізачію дисииплінарних норм.

Автор узагальнює положення щодо сутності державної дисципліни та залежність ї̈ ефективної реалізачії від: юридичної техніки (встановлених державою норм, правил, обов'язків, які зумовлені самою об 'єктивною реальністю) та суб 'єктивного чинника (підпорядкування суб' 'кта суспільних відносин встановленим нормам, правилам, обов 'язкам, щуо проявляється у фактичній правомірній поведінці суб 'єктів).

Визначено, що завдяки ефективному правовому регулюванні з дотриманням вимог юридичної техніки щодо змісту та письма нормативно-правових актів стає можливим покращити реалізацію дисииплінарних вимог, що містяться в зазначених нормах. Крім иього, за допомогою засобів законодавчої техніки (юридичних конструкиій, юридичних понять, юридичних термінів, правових презумпиій, правових фікцій) забезпечується техніко-юридична якість (змістова, структурна, стилістична) законів та зрозумілість й доступність ӥх адресату.

Підсумовано, щуо юридична техніка має важливе значення для зміџнення держаної дисиипліни: забезпечує доступність законодавства та зручність у його використанні; залежно від того, наскільки досконало, чітко та зрозуміло викладено думки законодавия чи інших суб'єктів правотворчості, залежить ї̈ правильне і адекватне розуміння та якість реалізаиії. Окрім изього, завдяки юридичній техніиі суб'єкт правовідносин може швидко і правильно відшукати ту норму, якою необхідно керуватися в тій чи іншій життєвій ситуації.

Сформульовано, що юридична техніка - ие один із чинників, який може забезпечувати правильне застосування та реалізачію нормативно-правових актів, у тому числі тих, що містять дисииплінарні вимоги; якість юридичної техніки є необхідною умовою для зміцнення державної дисиипліни та ефективності ї̈ реалізаџії.

Ключові слова: юридична техніка, державна дисиипліна, правотворчість, правозастосування, правове регулювання, нормативно-правовий акт, індивідуальний акт.

Постановка проблеми. Для сучасної юридичної науки й практики зміцнення державної дисципліни є надзвичайно актуальним питанням та впливає на ефективне виконання сучасною державою поставлених перед нею завдань. Як відомо, державна дисципліна характеризуються значним соціально-правовим впливом на суспільне життя, свідомість і поведінку людей. Ïї зміст охоплюють правила поведінки, що випливають із загальних правових актів (наприклад, ст. 139 КЗпП України, що містить загальні обов'язки працівника, працювати чесно, сумлінно тощо), індивідуальних правових актів (наприклад, наказ власника підприємства про відрядження працівника), норм моралі (наприклад, повага до старших людей), технічних норм (наприклад, необхідність дотримання технічних норм під час експлуатації машин та механізмів), інших соціальних норм (звичаї, релігійні норми тощо). Однак за допомогою змісту насамперед правових положень можна визначити, чи має суб' єкт право на певну поведінку (уповноважуючі правові норми), чи зобов'язаний суб' єкт до певної поведінки (зобов' язуючі правові норми), чи забороняється певна поведінка (забороняючі правові норми). Тому серед засобів зміцнення державної дисципліни необхідним є використання певних правил та методів, які застосовуються в процесі розроблення змісту та структури правових актів. Тобто вдосконалення сутності основних положень юридичної техніки сприятиме реалізації правомірної та соціально-корисної поведінки, в основі якої лежить розуміння відповідальності перед суспільством і державою за свої вчинки. 
Аналіз останніх досліджень і публікацій. Юридична техніка була предметом дослідження таких вчених, як Н. Власенко, А. Баранова, М. Давидова, Т. Дідич, О. Зацепіна, В. Карташова, Т. Кашаніна, В. Косович, Л. Луць, Г. Поліщук, О. Скакун, В. Томін та ін. Але варто зазначити, що, досліджуючи юридичну техніку, основну увагу вчені-науковці зосереджували на засобах юридичної техніки (правових презумпціях, фікціях, аксіомах). Питання впливу юридичної техніки на зміцнення державної дисципліни в юридичній науці практично не досліджувалося.

Постановка завдання. Метою дослідження $\epsilon$ теоретико-правова характеристика впливу юридичної техніки на зміцнення державної дисципліни.

Виклад основного матеріалу дослідження. Юридична техніка $є$ важливим інструментом у реалізації прав і законних інтересів громадян у різних сферах суспільного життя.

На думку А. Красницької, юридична техніка - це система заснованих на досягненнях теорії права і перевірених практикою правотворчості принципів, прийомів, засобів, правил (логічних, структурних, лінгвістичних) підготовки найбільш якісно досконалих за формою і структурою нормативно-правових і правозастосовних актів, що використовуються в процесі вироблення й систематизації актів для забезпечення їх досконалості. Засоби, прийоми, правила забезпечують повну i точну відповідність форми нормативних приписів їх змісту, точність, чіткість, правильність, доступність іпростоту нормативного матеріалу [1].

Юридична техніка як у правотворчості, так і в правозастосуванні має стосуватися кваліфікованого й досконалого викладу правового матеріалу, правильного утворення юридичних конструкцій і прийомів викладу правових норм, точності юридичних дефініцій, грамотного та зрозумілого словесного формулювання правових приписів.

М. Савчин зазначає, що юридична техніка служить дисциплінуючим фактором, бар'єром, перешкодою на шляху абстрактних домагань або самоуправних дій, спрямованих на охоплення правового простору. Вона надає знання про конкретні умови застосування будь-якого правового акта, дії чи ситуації [2]. Отже, є підстави стверджувати, що юридична техніка є необхідним інструментом для зміцнення державної дисципліни, законності тасприяє встановленнюправопорядку в суспільстві.

Як зазначає В.I. Лебеденко, юридична техніка в правотворчості охоплює нормативні акти, тобто техніко-юридичні прийоми і правила в процесі вироблення законів і підзаконних нормативноправових актів, а в правозастосовній діяльності індивідуальні акти, тобто техніко-юридичні прийоми і правила в процесі вироблення судових актів, договорів тощо. Від юридичної техніки значною мірою залежать ефективність законодавства в цілому, його правильне розуміння та використання суб'єктами правозастосування, його належний вид, систематизація тощо. Разом із тим, на думку вченого, значна частина чинних нормативних правових актів в Україні є неякісною з погляду на нормотворчу техніку. Невдалі формулювання або неточні вживання термінів, допущення суперечностей, некоректні посилання і т. ін. породжують зволікання, сприяють помилкам, виникненню непорозумінь у практичній правничій діяльності, заважають ефективному реформуванню багатьох сфер державного та громадського життя [3, с. 53].

Bсе це негативним чином вливає на державну дисципліну. Адже державна дисципліна $\epsilon$ виконанням обов'язків, що міститься у всіх правових актах (нормативних, правозастосовних, інтерпретаційних, договірних) та в інших соціальних та технічних приписах нормативного та індивідуального характеру. Зокрема, дисциплінарні норми можуть містити не тільки нормативно-правові вимоги, але й на індивідуально-правові, моральні, партійні та інші приписи . Однак, на нашу думку, саме в процесі реалізації норм державної дисципліни здійснюється виконання обов'язків, які містяться в законних та підзаконних актах (державна дисципліна тісно пов'язана із законністю). Отже, практична реалізація дисциплінарних норм залежить від юридично-технічної досконалості нормативно-правових актів.

На думку I. Шутака, варто розглянути питання про розробку та прийняття Закону України, зокрема «Про нормативно-правові акти». Відсутність Закону України про нормативно-правовий акт призводить до викривленого тлумачення норм права, що найбільш наочно виявляються у процесі застосування права. Закони пишуть не для юристів, а для звичайних людей, тому їх зміст має бути зрозумілий. Процес тлумачення відбувається переважно у свідомості людини у вигляді різних внутрішніх інтелектуально-вольових операцій (з'ясування вимог норм), які знаходять вираження зовні (роз'яснення) у вигляді інтерпретаційного акта, юридичної поради [4, с. 42].

В науковій юридичній літературі визначено, що предметом юридичної техніки $є$ найбільш загальні закономірності здійснення юридичної діяльності та іiі результати, що відображаються 
у змісті нормативно-правового чи індивідуального акта. Об'єктом юридичної техніки є текст нормативно-правового чи індивідуального акта [1].

Водночас, як зазначається в науковій літературі, сутністю дисципліни можна назвати певні вимоги до порядку поведінки людей в тій чи іншій сфері суспільного життя, що пов'язані з підпорядкуванням юридичним та іншим соціальним обов'язкам. Оскільки функціональне призначення юридичних обов' язків - виконувати свою частину роботи в механізмі правового регулювання, спрямовувати індивідів у потрібне русло, можна говорити про підпорядкування юридичним обов'язкам як правовому вираженню дисципліни [5, с. 35].

Отже, сутність державної дисципліни є багатоаспектною, що полягає у взаємозв 'язку насамперед 3 юридичною технікою як об'єктивним чинником (наявністю встановлених державою норм, правил, обов'язків, які зумовлені самою об'єктивною реальністю) та суб'єктивним чинником (підпорядкування суб'єкта суспільних відносин встановленим нормам, правилам, обов'язкам, що проявляється у фактичній правомірній поведінці суб' єктів).

Основним призначенням юридичної техніки $\epsilon$ точний, повний, чіткий, правильний виклад акту-волевиявлення в акті-документі, відображення в тексті документа справжньої волі правотворця/правозастосувача [1].

Формування правової поведінки суб'єкта суспільних відносин здійснюється двома шляхами: через правовий вплив та через правове регулювання. Правовий вплив, як правило, $є$ інформаційний та здійснюється з використанням системи неюридичних засобів (інформаційні, ідеологічні тощо). Щодо правового регулювання поведінки носія суспільних відносин, то юридична техніка входить до сфери нормативно-правового регулювання. Тобто низький рівень техніки юридичного письма як різновиду юридичної техніки, недосконалість структури та письмового викладу тексту - основні причини недієвості та низької ефективності українських законів та підзаконних нормативних актів. Текстуальна форма нормативно-правових актів має виразити специфіку правового регулювання, правове трактування, оцінку та кваліфікацію суспільних відносин. Така специфіка відповідно до юридично-доктринального трактування права як системи норм полягає в тому, що правове регулювання здійснюється за юридично-логічною моделлю норми права. Все, що в тексті нормативно-правових актів не $\epsilon$ вираженням елементів норми права і не пов'язане 3 ним, засмічує текст нормативно-правового акта, порушує юридичну логіку його побудови, ускладнює розуміння та застосування нормативно-правових положень [6].

Отже, завдяки ефективному правовому регулюванню 3 дотриманням вимог юридичної техніки щодо змісту та письма нормативно-правових актів можна покращити реалізацію дисциплінарних вимог, що містяться в зазначених нормах. Крім цього, за допомогою засобів законодавчої техніки (юридичних конструкцій, юридичних понять, юридичних термінів, правових презумпцій, правових фікцій) забезпечується техніко-юридична якість (змістова, структурна, стилістична) законів та зрозумілість й доступність їх адресату.

Крім цього, важливим питанням щодо зміцнення державної дисципліни, зокрема ії різновиду - трудової дисципліни, $€$ відповідність наказів чи локальних нормативних актів, що видаються окремими керівниками підприємств, установ, організацій тощо, приписам нормативноправових актів держави. На жаль, у практичній діяльності можлива така невідповідність, що проявляється у вигляді суперечностей між правовими приписами та розпорядженнями окремих посадових осіб, що виникає внаслідок перевищення службових повноважень чи зловживання ними. Приміром, наказ керівника підприємства про відрядження співробітниці, в якої є дитина віком до трьох років, безумовно, суперечитиме режиму законності в державі (ст. 176 КЗПП України) [7, с. 73]. Тому відмова від відрядження не може кваліфікуватися як порушення трудової дисципліни. Відповідно, видача такого наказу керівником підприємства буде вважатися порушенням трудового законодавства.

Тому, встановлюючи принцип безумовного підпорядкування наказам керівників, держава виходить із презумпції законності цих наказів. Отже, наказ має відповідати певним вимогам, тільки за умови виконання яких він буде правовим, матиме юридичну силу та користуватиметься захистом із боку держави. Насамперед, наказ не може суперечити Конституції України, законам України, указам Президента України та постановам уряду.

Еталони (моделі) правової поведінки мають бути нормативно закріплені в системі законодавства. Таке закріплення забезпечує громадянам визначеність у поведінці, віру в досягнення необхідних результатів. Цьому ж сприяє і порівняна стабільність законів, стійкість практики їх застосування, прийнятність методів роботи правоохоронних органів незалежно від зміни конкретних посадових осіб. Стабільність правового регулю- 
вання породжує впевненість у тому, що відповідні правила поведінки не випадкові, а корисні та необхідні, що вони відображають об'єктивні потреби життя та потребують безумовного виконання [8].

На думку Г. Молєва, в юридичному розумінні дисципліна $\epsilon$ підпорядкуванням обов'язків, що містяться в правових актах (нормативних, правозастосовних, інтерпретаційних, договірних) та інших соціальних та технічних приписах (нормативних, індивідуальних), що мають за мету упорядкувати визначені суспільні відносини [5, с. 32]. Отже, «якість юридичної техніки» впливає на поведінку громадян, а також на те, як саме відбудеться реалізація державної дисципліни (чи зрозумілі її дисциплінарні вимоги адресатові).

Г.Б. Поліщук наголошує на певних принципово теоретичних аспектах, що характеризують поняття «юридичної техніки» не лише як сукупність певних правил і принципів, а й як засіб оцінки рівня якості, логічної послідовності змісту проєктів нормативно-правових актів та чинних юридичних документів, що становлять систему законодавства [9, с. 72].

Постійне та своєчасне удосконалення чинного законодавства, в тому числі й за допомогою засобів юридичної техніки - це один із пріоритетних шляхів зміцнення державної дисципліни. Відомо, що юридично правильне, всебічне врегулювання суспільних відносин здійснюється шляхом удосконалення, своєчасного оновлення та видання нових нормативних актів. Крім цього, зміни в соціально-економічному та політичному житті суспільства, виникнення нових суспільних відносин, наявність недосконалих норм права, колізійних норм та інші причини вимагають удосконалення та своєчасного оновлення чинного законодавства. Завдяки цьому держава має змогу впливати на стан державної дисципліни. Зокрема, у процесі видання компетентним державним органом або уповноваженим ним суб' єктом правового акта, який регулює ті чи інші суспільні відносини та містить загальні правила і вимоги дисциплінарного характеру, що адресуються конкретно визначеному суб'єкту. Крім цього, про необхідність удосконалення та оновлення чинного законодавства переконливо свідчать також часті порушення реалізації державної дисципліни, особливо таких iii різновидів, як фінансова, договірна, трудова дисципліна та ін.

Висновки. Юридична техніка має важливе значення для зміцнення держаної дисципліни. Адже, як відомо, юридична техніка забезпечує доступність законодавства та зручність у його використанні. Тому залежно від того, наскільки досконало, чітко та ясно викладено думки законодавця чи інших суб'єктів правотворчості, залежить ії правильне і адекватне розуміння та якість реалізації. Крім цього, соціальним призначенням юридичної техніки, зокрема правотворчості, є встановлення стандартів, еталонів, взірців поведінки учасників суспільних відносин. Тобто завдяки юридичній техніці суб'єкт правовідносин може швидко і правильно відшукати ту норму, якою необхідно керуватися в тій чи іншій життєвій ситуації. Таким чином, юридична техніка - це один із чинників, який може забезпечувати правильне застосування та реалізацію нормативно-правових актів, у тому числі тих, що містять дисциплінарні вимоги. При цьому, як відомо, законність є основою державної дисципліни. Тому якість юридичної техніки $\epsilon$ необхідною умовою зміцнення державної дисципліни та ефективності їі реалізації.

Це дослідження не претендує на вичерпний опис усіх аспектів впливу юридичної техніки на зміцнення державної дисципліни, що існують у теорії права. Важливо зазначити, що ефективна практична реалізація дисциплінарних норм залежить від юридично-технічної досконалості нормативно-правових актів. Тому вважаємо цей напрям дослідження актуальним та перспективним для подальшого вивчення юридичної техніки як інструменту зміцнення державної дисципліни.

\section{Список літератури:}

1. Красницька А.В. Юридичні документи : техніка складання, оформлення та редагування : посібник 2-е вид., допов. і перероб. Київ : Парламент. видавництво, 2006. 538 с.

2. Савчин М. Методологія порівняльного правознавства у контексті зближення правових культур та соціогуманітарного виміру права. URL: https:// dspace.uzhnu.edu.ua/jspui/handle/lib/5229 (дата звернення: 12.01.2021).

3. Лебеденко В.I. Юридична техніка: поняття, призначення, методологічні засади застосування. Інформаиія і право. 2014. № 2(11). С. 52-56.

4. Шутак І. Юридична техніка і технологія: теорія та практика застосування. Вісник Львівського університету. Серія юридична. 2016. Випуск 63. С. 37-45.

5. Молев Г.И. Дисциплина в российском обществе: теоретико-правовой аспект : дис. ... канд. юрид. наук : 12.00.01. Саратов, 2005. 203 с. 
6. Нерсесянц В.С. Общая теория права и государства : учеб. для юрид. вузов и фак. Москва : НОРМАИНФРА-М, 2000. С. 427.

7. Кодекс законів про працю України : Закон України прийнятий Верховною Радою України від 10 грудня 1971 p. № 322-08. Дата оновлення: 31.12.2020. URL: https://zakon.rada.gov.ua/laws/show/322-08\#Техt (дата звернення: 12.01.2021).

8. Кудрявцев В.Н. Законность: содержание и современное состояние. Законность в Российской Федерации. Москва : Спарк, 1998. 213 с.

9. Поліщук Г.Б. Місце та значення юридичної техніки в процесі кодифікації законодавства. Часопис Київського університету права. 2010. № 4. С. 70-73.

\section{Mozoliuk-Bodnar L.M. THE INFLUENCE OF LEGAL ENGINEERING ON STRENGTHENING STATE DISCIPLINE: THEORETICAL ASPECT OF RESEARCH}

The article analyzes the impact of legal techniques on strengthening state discipline. It is determined that the main purpose of legal technique is: accurate, complete, clear, correct statement of the act of expression of will in the act-document, reflection in the text of the document of the true will of the legislator. The quality of legal techniques affects the implementation of disciplinary rules.

The author summarizes the provisions on the essence of state discipline and the dependence of its effective implementation on: legal techniques (established by the state norms, rules, responsibilities, which are due to the most objective reality) and the subjective factor (subordination of the subject of social relations to established norms, rules, responsibilities, which is manifested in the actual lawful conduct of the subjects).

It is determined that due to effective legal regulation in compliance with the requirements of legal techniques on the content and writing of regulations, it becomes possible to improve the implementation of disciplinary requirements contained in these rules. In addition, with the help of legislative techniques (legal constructions, legal concepts, legal terms, legal presumptions, legal fictions) provides technical and legal quality (semantic, structural, stylistic) of laws and clarity and accessibility to their recipient.

It is concluded that legal technique is important for strengthening state discipline: it provides accessibility of legislation and convenience in its use; Depending on how perfectly, clearly and intelligibly set out the views of the legislator or other lawmakers depends on its correct and adequate understanding and quality of implementation. In addition, thanks to legal techniques, the subject of legal relations can quickly and correctly find the rule that must be followed in a given life situation.

It is formulated that legal technique is one of the factors that can ensure the correct application and implementation of regulations, including those that contain disciplinary requirements; the quality of legal equipment is a necessary condition for strengthening state discipline and the effectiveness of its implementation.

Key words: legal technique, state discipline, law-making, law enforcement, legal regulation, normativelegal act, individual act. 